\title{
Good Nuclear Neighbours: the British electricity industry and the communication of nuclear power to the public, 1950s-1980s
}

\section{Thomas Lean and Sally Horrocks}

\begin{abstract}
Between the 1950s and the 1980s the British nuclear industry engaged with ordinary people in a wide range of ways. These included articles in the print media, exhibitions and educational resources as well as through open days, developing nature reserves and building relations with the local communities around nuclear sites. This paper draws on recently collected oral history interviews and archival material to consider what was one of the largest and best resourced efforts to communicate science to the British public between the 1950s and the 1980s.
\end{abstract}

Keywords

History of public communication of science

Introduction

In September 1977 around 240 Monopoly gamers gathered in the cavernous reactor hall of Oldbury nuclear power station, on the banks of the River Severn in South West England. They were there for the finals of the British Monopoly championships and for two days sat playing Monopoly atop the pile cap. Directly beneath them were thousands of uranium fuel rods quietly undergoing nuclear fission to produce the heat that would eventually generate hundreds of megawatts of electricity. The players had quite literally landed on The Electric Company, who were very glad to have them there, the event providing a 'publicity godsend for the CEGB (Central Electricity Generating Board)' [Page, 1977].

Monopoly on a nuclear reactor was just one of a range of ways the British nuclear electricity industry used to engage with ordinary people and share information about its activities. It also supported the development of nature reserves, looked after fish stocks, organised open days and built relations with the local communities around nuclear sites, in which many of its staff lived. Information about nuclear power was distributed through the print media, exhibitions and films. This range of activities, dating back to the earliest years of the nuclear industry, has not been subjected to detailed scholarly scrutiny, in contrast to the nuanced accounts of the campaigning efforts made by its opponents [Wynne, 1982; Rüdig, 1994; Welsh, 1989; Welsh, 1993; Welsh, 2000]. The coverage of the industry in the media has generally been dismissed as part of an 'official' narrative, and as symptomatic of its failure to go beyond the deficit model of public understanding of science, but scholars have said little about the other ways that it used to engage 
with ordinary people. This may arise from having to interpret the industry's activities without access to its internal debates or information about how these activities were understood and managed by insiders. As a result we know little about one of the largest and best resourced efforts to communicate science to the British public between the 1950s and the 1980s.

This paper addresses this lacuna, by drawing on recently collected oral history interviews from the British Library National Life Stories project An Oral History of the Electricity Supply Industry in the UK. ${ }^{1}$ The collection includes interviews with many individuals connected with nuclear power, such as industry leaders and power station designers and managers. As autobiographical life story interviews, they are not solely concerned with nuclear power nor the public understanding of science, but the details of daily life they recover show that explaining science to the public was an implicit part of the job. The interviews provide an insider's view of the nuclear industry, a way of understanding not just what it did but why it did it. We use these interviews alongside archival material to consider the many different ways in which the industry engaged with ordinary people and how these evolved between the 1950s and 1980s.

The British nuclear power industry was a diverse constellation of interests. As well as many private engineering companies who designed and built the power stations, it included the UK Atomic Energy Authority (UKAEA) and from 1971 the state owned British Nuclear Fuels (BNFL). UKAEA focused on research and development, but also ran a few, partly experimental, nuclear power stations. However, our main area of inquiry here is the Central Electricity Generating Board (CEGB), Britain's nationalised electricity generator, which operated almost all the nuclear power stations in England and Wales as well as having a major role in their planning and design. ${ }^{2}$ While the CEGB is our focus, in practice these organisations cooperated in how they presented nuclear power to the public.

We make three arguments. Firstly that public engagement was both direct and indirect and operated at both local and national levels. Secondly that by opening up its sites and working with local communities the industry effectively tapped in to an appetite among ordinary people for knowledge based on personal experience. Finally we argue that while the content of much public facing material could be read as conforming to the deficit model, and the public pronouncements of industry leaders interpreted in this way, the industry actually had a much more nuanced understanding of the knowledge practices of ordinary people than this crude characterisation suggests. This paper looks first at the years between the 1950s and 1970s, when opposition to nuclear power stations was a relatively minor issue and tended to be concentrated at a local level. It then considers how growing concerns over nuclear power in the 1970s changed the nature of opposition and forced the CEGB to reconsider its efforts to secure and sustain public trust. The focus of the analysis is on how the industry presented itself to the public and we make no judgements about the merits of its case.

\footnotetext{
${ }^{1}$ For further information on this project see An Oral History of the Electricity Supply Industry in the UK at https: / / www.bl.uk/ projects / national-life-stories-an-oral-history-of-the-electricity-supplyindustry-in-the-uk (visited on 11th December 2016).

${ }^{2}$ The electricity supply industry in Britain was nationalised in 1947, with its power stations in England and Wales the responsibility of the British Electricity Authority (BEA), subsequently reorganised in the Central Electricity Authority (CEA) in 1955, then the CEGB from 1957 until its break up and privatisation in 1991. A separate, though linked, organisation existed in Scotland.
} 
Presenting nuclear power nuclear landscapes
The early years of civil nuclear power are often seen as being marked by optimism for this new technology. Compared to the horrors of the atom bomb, civil nuclear power held out the futuristic promise of cheap, clean and unlimited electricity. In 1956 Queen Elizabeth II opened Calder Hall, the first full sized nuclear power station to supply electricity to the public in the world, declaring 'this new power, which has proved itself to be such a terrifying weapon of destruction, is harnessed for the first time for the common good of our community' [BBC News, 2008]. Closer examination reveals that perceptions of this new technology were more complicated. In 1957 a fire in a reactor at Windscale used to produce plutonium for the military resulted in a serious nuclear accident that caused public disquiet. As Ian Welsh has shown, there was opposition to the building of nuclear power stations and public concerns about their safety from the beginning [Welsh, 1989; Welsh, 1993]. Even within the nuclear industry there were cautious voices. In the 1950s UKAEA enthusiastically foisted an ambitious atomic programme onto the electricity supply industry, but the more sceptical CEGB gradually scaled it back to something it thought more realistic [Hannah, 1982].

Nevertheless nuclear power was important to the electricity supply industry, for it emerged at a time of huge industry expansion. Electricity demand was growing sharply and the major drive of the industry was to build enough new power stations to meet it, and to replace old uneconomic stations inherited when the industry was nationalised in 1947. Between 1950 and the early 1970s over sixty new power stations were built in Britain, including the first eleven nuclear plants, which used the Magnox design. The Magnox stations were followed by seven more powerful Advanced Gas Cooled Reactors [AGR] commissioned in the 1970s and 1980s, and a sole Pressurised Water Reactor [PWR] completed in $1995 .^{3}$ The industry faced a statutory requirement to protect the environment in the case of all power stations, but the location of nuclear plants in undeveloped rural areas necessitated particular care. Under section 37 of the 1957 Electricity Act electricity boards were obligated to the 'preservation of amenity,' including the conservation of natural beauty, flora and fauna. As John Sheail comprehensively documents, the industry made extensive efforts to do so [Sheail, 1991].

To get its power stations approved and built with the minimum of delay, the industry sought to accommodate the concerns of a variety of conservation groups, both locally and nationally. CEGB station planner Michael Gammon recalled how it was standard practice to engage with the local branches of established groups at an early stage:

\footnotetext{
'You would always be talking to the local branch of Nature Conservancy, Countryside Commission, Royal Society for the Protection of Birds, National Trust if they were around, as well as the local authorities' [Gammon, 2014, Track 6].
}

Gammon also set up annual national level meetings with such organisations. The CEGB went to some lengths to accommodate conservationists and protect wildlife. At Dungeness, for example, they preserved old railway sleepers as a habitat for

\footnotetext{
${ }^{3}$ The Magnox stations were: Calder Hall, Chapelcross, Berkeley, Bradwell, Hunterston A, Hinkley Point A, Trawsfynydd, Dungeness A, Sizewell A, Oldbury and Wylfa. The AGRs were Dungeness B, Heysham 1, Heysham 2, Hinkley Point B, Hunterston B, and Torness. Sizewell B was the sole PWR.
} 
moths and supported the bird observatory. Near Sizewell, they supported RSPB warden Bert Axell's construction of the Minsmere nature reserve. 'Most of the paths in the RSPB were made from surplus hardcore from Sizewell A,' recalled Michael Gammon, who struck up a friendship with Axell whilst both were on the committee of the Dungeness bird observatory. '[Axell] also borrowed quite a bit of equipment... And we used to provide him with fish caught on the cooling water screens for him to seed The Scrape [lagoon]' [Gammon, 2014, Track 1]. Nature reserves and trails were established at several power stations, part of a wider attempt to them fit into their surrounding environment and to provide amenities for the local population.

Efforts were also made to ensure that power stations harmonised with their local surroundings, acknowledging that they could not be hidden. The Royal Fine Art Commission had a role in approving the design of power stations. The visual impact of new developments came to increasing prominence in 1957 after the appointment of Sir William Holford, University College, London Professor of Town Planning, as a part time member of the CEGB board [Miller, 2004]. Holford took an active role in helping the CEGB preserve amenity, encouraging the use of architects and landscaping consultants [Sheail, 1991]. Only so much could be done to match a nuclear power station with its location, but the evidence suggests that the industry took this seriously. As Sir Christopher Hinton, CEGB chairman, explained, 'We are trying to do a functional job and at the same time to pay the utmost possible regard to the landscape' [Hinton and Holford, 1960]. The effort varied, but perhaps the best example is at Trawsfynydd in North Wales. Although the immediate area was generally reckoned unattractive by the standards of the district, its location within a national park was controversial. To head this off the CEGB commissioned architect Basil Spence, whose credits included Coventry Cathedral. He produced a strikingly modernist design. Michael Gammon recalled,

\footnotetext{
'there were some very odd comments about the design of Trawsfynydd, Basil Spence put something up there that was not generally liked by the Arts Commission... but they said: "He is a genius, we must respect him" ' [Gammon, 2014, Track 3].
}

Despite these initial reservations the end result, appearing almost as a twin towered concrete castle set beside a lake, was deemed to fit its surroundings. 'The neo-brutalism of the design is swallowed in the brutal peaks of Snowdonia,' mused a visiting journalist, noting that the CEGB described it as 'the newest castle in Wales, housing more power than the old feudal lords could ever imagine' [The Guardian, 1962]. Attention was also given to landscaping, with consultant Sylvia Crowe including flourishes such as a mosaic Welsh dragon, said to be a concession to the nationalist sentiments of the local population. The CEGB even stocked the lake with rainbow trout for anglers [Sheail, 1991].

Trawsfynydd was probably an extreme example of the lengths the CEGB went to in ornamenting its nuclear sites, but it was not alone. In 1968, Country Life, an up-market rural lifestyle magazine, devoted a feature to 'the nuclear landscape,' noting the attractive 'extreme cleanliness' and neatness of nuclear power stations. Country Life found much to admire in their architecture and landscaping, from the 'striking, even elegant,' Oldbury, 'likened by the casual observer to a cathedral', to 
the 'sharp, clean outline' of the 'interestingly different' Trawsfynydd. ${ }^{4}$ Yet overall, Country Life complained, 'they fail to stimulate the excitement which should be associated with the exotic technology,' concluding that:

'it is almost as if [the CEGB] has been so successful in its collaboration with preservation societies and the Fine Arts Commission, that the latest nuclear plants have attained a relative obscurity' [Rippon, 1968].

Good nuclear neighbours

The CEGB used conservation, architecture and landscaping as almost a visual form of science communication, trying to adapt its nuclear stations into their surroundings in a way that would make nuclear power acceptable to a variety of audiences. These efforts to preserve amenity indicate how the industry took considerable pains during the development phase to shape the way the public would see nuclear power. Although the definition of amenity did not explicitly cover social issues, the industry also promoted the positive economic effects of nuclear power stations for local communities, even though these were smaller than many expected. At Trawsfynydd, an area of high unemployment, the public inquiry was greeted by supportive locals waving banners with such slogans as 'Pylons before poverty' and 'Objectors you are not welcome.' According to The Manchester Guardian, 'every square foot' of the village hall was occupied and locals accompanied the proceedings with 'clapping, stamping, cheering, and with occasional booing' [The Guardian, 1958].

Not all public inquiries were as marked by public support as at Trawsfyndd. Ian Welsh's examination of those for Bradwell and Hunterston reveals local opposition to nuclear power stations from the start of the programme [Welsh, 1989]. Local campaign groups were formed, to which the industry responded with exhibitions, educational films and public meetings. Nuclear safety concerns were raised by objectors at inquiries, prompting responses from industry experts. Previous scholars have been divided on the extent to which public enquiries were effective at diffusing public concerns about nuclear power [Welsh, 1989; Rüdig, 1994]. However, to the CEGB they contributed to the influencing of public perceptions before stations were built. 'As a means of public communication a Public Inquiry has some advantages,' explained Michael Gammon, noting media coverage, a chance for objectors to air their points and for cross examination of the arguments [Gammon, 1981].

Operational stations developed an ongoing interaction with local communities. Each site had a Local Liaison Committee including local authorities, community representatives and the emergency services; partly in case of accidents, but also because 'these people have very wide contacts and are expected to act as effective channels of communication back to the whole community' [Gammon, 1981]. Alongside these formal channels, there could be an informal ambassador role for staff members living in the local area too: 'One had to take the nuclear power station into the local community as a way of assuaging the fear that politicians and people had,' noted Heysham deputy manager Granville Camsey [2014, Track 6].

\footnotetext{
${ }^{4}$ It should be noted that the team effort was somewhat let down by the visually unhappy Sizewell, 'loom[ing] ominously over the pleasant green fields [Rippon, 1968].
} 
These links seem part of an effort to portray nuclear power stations as responsible actors in the community. This was improved further by station management offering entrance to nature reserves, to their sports and social facilitates and allowing the public access. 'Good local relations are also fostered by access to stations for open days and other ways in which the station conscientiously tries to be a good neighbour,' explained Michael Gammon [1981]. This accessibility extended beyond the local community as power stations, many built in picturesque countryside, became visitor attractions more or less by accident. In 1967 The Guardian wrote of the 'lure of nuclear power stations' for tourists, noting that Trawsfynydd received 8,000-10,000 visitors a year. The under-construction Wylfa station was already recruiting women tour guides with a 'sound knowledge of general science to $\mathrm{O}$ Level at least' in anticipation of the demand from visitors [The Guardian, 1967]. In the mid-1970s Tom McInerney, manager of Hinckley Point organised an open day, which unexpectedly drew a 'tremendous crowd' after the Automobile Association signposted the event. Although this strained the supply of tea and buns at the canteen, the end result was judged a success, as McInerney later recalled.

'It was a good day in as much as if you wanted to get to a large group of the public, you did it... In those days there was the freedom of walking around... people could walk on the reactor tops and we could say "you're standing on top of an on-load reactor, you know?" So I think it did a lot of good' [McInerney, 2014, Track 6].

Many station visitors came on trips organised for various societies, Rotary clubs, Women's Institutes, school groups and others. Letting ordinary people inside its stations enabled the industry to open up the black box of the nuclear power station, demystifying it by allowing them to see for themselves. This was important at a time when, as Langhamer has suggested, ordinary people were coming to rely more and more on personal experience as a basis for knowledge. Visiting a nuclear power station did not mark them out as passive recipients of industry propaganda, but as active participants in their own knowledge practices [Langhamer, 2016]. Oldbury power station manager Peter Webster suggests this when he recalled of visitors during the 1990s that:

\footnotetext{
'Most, I found were, they're almost in awe of the scale... If you come and have a look you might not be so worried about it... I think it probably worked, to be honest, with an awful lot of people, they felt more comfortable because they' $\mathrm{d}$ been there, they'd been in. . . come out and all was well' [Webster, 2016, Track 6].
}

By engaging with ordinary people in a range of ways, the CEGB demonstrated an implicit awareness that sustaining public confidence in nuclear power required a repertoire of approaches, and that the core message of safety and reliability could be communicated indirectly as well as directly. Simply by allowing people close contact with nuclear sites as places of leisure in the form of nature trails, sports facilities and tourist attractions they became normalised into everyday routines and allowed individuals to use their own experience to reach conclusions about safety and reliability. For local communities this confidence was also fostered by living alongside those who operated the station, facilitating the development of trust at a 
personal level, rather than the impersonal assurances offered by men in grey suits [Welsh, 2000]. ${ }^{5}$

The rise of opposition
The 1970s are frequently seen as a watershed in public attitudes toward nuclear power [Rüdig, 1994]. Previously the strongest opposition had come at local level, but the decade saw the rise of national environmental groups, notably Friends of the Earth and Greenpeace, whose opposition was more fundamental than the conservation groups the CEGB had accommodated in the past. These groups took an increasingly active role in opposing nuclear developments, as did the National Union of Mineworkers who had a vested interest in limiting expansion. The issue of nuclear waste also came to growing prominence, particularly after the 1976 Flowers Report, Nuclear Power and the Environment, advised against future nuclear power stations until a satisfactory long term solution had been found to the problem of radioactive waste [Royal Commission, 1976]. A year after the Flowers Report the Windscale Inquiry into a new nuclear reprocessing facility became a subject of public controversy, credited by Rüdig with causing a shift in public attitudes against nuclear power [Rüdig, 1994]. In 1979 Three Mile Island, a US reactor in Pennsylvania, suffered a partial meltdown, further enhancing the climate of suspicion. During the 1980s, the industry was challenged by a popular culture that was, as Hogg has recently argued, 'saturated with unofficial nuclear narratives.' These concentrated primarily on the threat of nuclear war, but also included negative responses to nuclear power as part of the nuclear state, particularly after the 1986 Chernobyl disaster [Hogg, 2016, chapter 6].

Perceiving this shift in attitudes, the industry responded by increasing and diversifying its communication efforts. As part of a wider industry drive it staged exhibitions, produced leaflets and courted the media. Alongside this broadcasting of information, it engaged with the public, preparing a cadre of selected speakers to talk and debate nuclear power in public forums and opened visitor centres at nuclear power sites. During the public inquiry for Sizewell B it mobilised its resources to defend the industry in what became a wide-ranging examination of the case for nuclear power. In 1984 it spent $£ 4$ million staging a train crash as a public demonstration of the integrity of nuclear fuel flasks. After the Chernobyl disaster there was an extensive media campaign, including a video explaining the CEGB view that such an incident could not happen in the UK. There was a two stream approach running through many of these efforts. On one hand was a tendency to bombard ordinary people with detailed technical explanations. These were intended by their creators to enhance understanding and appeal to reason, but they now seem to have been pitched at a level unlikely to appeal to non-experts. However this supply of facts was tempered by more nuanced approaches and enhanced opportunities for people to gain personal experience by visiting stations and meeting their staff.

To coordinate this diverse effort, the industry established The Nuclear Power Information Group (NPIG) with membership from across the sector to present a unified case for nuclear power. Its activities were wide ranging, including

\footnotetext{
${ }^{5}$ According to Welsh the light grey suit was part of a uniform adopted by industry representative at public meetings. He claims that 'As a genre this style of dress was completely unexceptional within the industry but in public forums its signature was one which evoked suspicion', Welsh [2000, p. 185].
} 
publications, films, interviews, debates, promotional material, talks and exhibitions. Between 1979 and 1981 the NPIG exhibition 'Atoms for Energy' visited 20 cities, with sections devoted to the need for nuclear power, nuclear safety, electricity generation, and the future of nuclear power. It also took out adverts in the press asking people to write in if they wanted further information declaring that, 'quite simply we want our critics - and our supporters - to be fully informed' [NPIG, 1980]. These efforts of the industry to disseminate information were extensive. In 1982 the Electricity Council, the electricity supply industry's coordinating body, reported it had recently distributed 294,000 pamphlets and booklets with such titles as Nuclear Power and the Public Good, not to mention 124,700 pro-nuclear car stickers and 38,500 badges [Maybury, 1982].

Alongside explanation of how atomic generation worked, the picture of nuclear power which the industry sought to portray was fairly consistent. 'I was trying to paint really a source of in-house energy in this country, which was very clean and safe,' recalled Peter Vey, UKAEA Director of Information services in the late 1970s [Vey, 2016, Track 7]. Nuclear power was presented as necessary for Britain to meet its requirements and maintain security of energy supply. It was, according to The Need for Nuclear Power, an Electricity Council pamphlet distributed to the public and issued as a guide to industry staff, 'the only established technology capable of substituting for our failing resources of oil and gas... no credible alternative exists' [Electricity Council, 1979]. The economic case was also often made, even if the costs of nuclear power were later shown to be far higher than estimated.

Much effort was given to addressing concerns about safety, risks to the environment, and the problem of nuclear waste. These were generally tackled by adopting a reassuring tone, which calmly stressed the professionalism of the nuclear industry and the copious efforts it made to ensure the safety of its own staff and the general public. This was buttressed with detailed facts, diagrams and technical explanations, for example:

\footnotetext{
The average ground radiation level is 15 radiation units a year, or 150 units if you live in a granite house in Aberdeen... The additional radiation levels near a nuclear power station are a tenth of a unit of radiation a year...So you can see, it is quite safe to live near a nuclear power station [Electricity Council, 1979].
}

Engaging with the public
In pamphlets such as The Need for Nuclear Power, the industry adopted a technocratic approach to dealing with the public; it supplied information, argued the case, and appealed to reason. Whilst the large numbers of publications issued suggest the industry merely tried to smother concerns with information, it could actually be extremely nuanced in its approach, targeting specific segments of the population in particular ways. It provided speakers for schools, for example, to which it also offered educational films, such as The Magic Metal Uranium (1985) and free books and 'Life with Nuclear Energy' wall charts. Symptomatic of the changing public mood, these efforts were contested by environmentalists who offered more critical teaching packs, films and books, such as Nuclear Energy Questions (1981). For its part the industry was quick to respond to slighting of nuclear power in the media, employing a cuttings service to monitor newspapers and correcting errors of fact or rebutting criticism through letters to the editor. 
Efforts were also made to build relationships with journalists, politicians and other opinion formers, such as pleasant dinners accompanied by presentations and discussion, and industry stands at political party conferences. Women were another group recognised as needing special consideration. Peter Vey, for example, recalled helping to set up an interview for UKAEA chairman Walter Marshall, who later became chairman of CEGB, on the Radio 4 programme Women's Hour:

\begin{abstract}
'The logic was that women were more worried about the issue than men... [Marshall] was appearing on Women's Hour to explain how important nuclear energy could be in pushing down electricity prices and therefore helping households and their budgets... and explaining some of the issues' [Vey, 2016, Track 7].
\end{abstract}

Alongside broadcasting this information, the industry tried to engage and debate with people in person, such as through the CEGB's Energy Talks Service, established in the late 1970s. Over 200 speakers delivered 1,300 talks to over 50,000 people in 1981 alone [Maybury, 1982]. Granville Camsey recalled that:

\begin{abstract}
'The Board became very alarmed at the critique in the public domain about nuclear power, so they pulled together a number of people... whose job it was to get out into the towns and women's guilds, the local library, the working men's clubs, any group who would be willing to listen to the nuclear power story and its benefits,' [Camsey, 2014, Track 5].
\end{abstract}

Camsey himself was trusted enough as a speaker to debate the merits of nuclear power with the formidable National Union of Mineworkers' General Secretary Arthur Scargill at a working men's club. Senior figures in the industry were very aware of the importance of selecting speakers who could engage with their audiences as well as supply facts, though this was not always easy and sometimes efforts fell short. As a UKAEA scientist lamented in 1981:

'We are not getting the nuclear message across because we are not fielding the right sort of people [...] At best their message comes over as some mixture of the impersonal, bureaucratic, technical, probably sincere, sometimes rather glib. At worst (although rarely, I believe) we field people with no aptitude for public speaking of any sort' [Clarke, 1981].

These efforts to counter opposition to nuclear power became more important to the industry during the early 1980s as the CEGB pressed ahead with a new nuclear power station programme. This anticipated as many as ten PWR stations, the first of which was proposed for Sizewell, alongside the existing Magnox station. Internal documents reveal that senior industry figures were concerned that existing public relations efforts had not been as effective as hoped, placing this programme at risk. Writing to the CEGB board about public attitude surveys around Sizewell in 1982, board member John Baker (later Sir John Baker) suggested that the issue was not simply public fears about a nuclear accident or other issues, but that it had failed to connect with the public.

'Too many people think we are secretive and are not giving them the full facts, or simply don't tell the truth... They don't believe we have the dangers under 
control... At simplest, we should, on the merits of the case, be convincing the public that nuclear power is clean, safe and cheap - and that it safeguards the future of their children. But we are not. Only a derisorily small percentage have seen our exhibition. Even the antis call for more information from us... Our case is simply not getting across. Few people understand or believe what we say [Baker, 1982].

Baker's conclusion, 'more effort, more cash and more imagination is required,' set the scene for an audacious initiative. This came in response to a growing campaign against the transportation of nuclear fuel flasks by rail. Although from an industry perspective the integrity of the flasks had been proved through calculation and experiment, the image of nuclear waste travelling close to peoples' homes was used effectively by anti-nuclear campaigners. Baker recalled that 'The anti lobby always seem to have the best tunes... they tended to be younger, articulate non-scientific types who would bravely make outlandish claims'. In contrast he saw the industry response as 'long winded, very, very scientifically based rejoinders, which nobody took any notice of, or could understand' [Baker, 2013-2014, Track 7].

To counter this, the CEGB, to use Harry Collins' phrase, embarked on a 'display of virtuosity' in 1984, by crashing a speeding train into a nuclear fuel flask as a public demonstration of the flask's integrity [Collins, 1988]. The enormous explosion and examination of the intact fuel flask was performed in front of an arena of spectators and broadcast on live television, with videos and sets of photographs issued afterwards. It is perhaps another example of experiential knowledge at work, the CEGB allowing people to witness with their own eyes how strong the fuels flasks were and then make up their own minds. Afterwards CEGB Chairman Walter Marshall told journalists, 'the general public made the point that... we've got to take the word of you experts on it, we're not going to be believe that, we want to see you actually do it. So well now we've done it' [Marshall, 1984]. To John Baker the event had achieved its objectives:

\footnotetext{
'That was the first time I felt we have found a technique that could challenge the anti-nuclear lobby on its own ground and frankly we never heard any problems again about the transportation of the fuel rods. [...] It cost the British electricity consumer $£ 4$ million to stage the event, but I thought that was about the best money I ever authorised. And it was it was a huge day out' [Baker, 2013-2014, Track 7].
}

The industry sought to demonstrate its openness and provide an opportunity for ordinary people to see for themselves by opening visitor centres that proved highly popular with both schools and tourists. In 1986 the new Hartlepool 'energy information centre' had pulled in 10,000 people by summer [Morris, 1986]. The most popular was at the British Nuclear Fuel Sellafield site, (also home to the Calder Hall power station), which saw 104,000 visitors in 1987 and was the fastest growing tourist attraction in England in 1988 [Morris, 1988]. As Peter Webster recalled of visitor centres:

'They were put up at a time when the nuclear business felt it had an image problem, too secretive, I mean nobody knows what's going on, why don't we make ourselves a little more open to the public... let's build some visitors 
centres, let's put stuff in them that explains radioactivity and power stations and how they work, let's put some people in there who can talk about it... Let's say to people if you turn up at the visitor centre then we'll organise a tour of the power station... It's the come look, see thing, and I think that's where it came from [Webster, 2016, Track 6].

Nuclear power on trial

While the role of visitors' centres in communicating nuclear power to ordinary people appears unambiguous, the part played by the Sizewell B public inquiry is more complex. The inquiry was a long drawn out affair. In 1955 the Bradwell Inquiry lasted 5 days. Sizewell B ran for 340 days of evidence over 1983-1985 and the inspectors' report was not issued until 1987. Rather than settling local issues, as was usually the case, this inquiry ranged more widely, as John Baker, the CEGB's principle policy witness recalled: 'Every conceivable subject, real, imaginary and fanciful got aired in this inquiry' [Baker, 2013-2014, Track 6]. Analysis of the inquiry by Richard Davies argues that it was more an exchange of monologues than a dialogue. Furthermore the way '[the inquiry's] procedures are overwhelmingly grounded in 'evidence' and 'facts' not in opinions, values or beliefs,' suited the CEGB, which was well prepared to argue the facts and win the major arguments [Davies, 1987]. John Baker recalled 14 wooden boxes stored in his car containing a vast range of information about the history of nuclear power and its operation. 'All the time I was in my car, I read these papers again and again and again, and then I would hold meetings with the barristers and get them to dummy run the inquiry, firing questions at me' [Baker, 2013-2014, Track 6].

The proceedings themselves were of a quasi-judicial nature, although there were protests, humorous episodes, and efforts to communicate clearly, as John Baker recalled his own 19 days on the witness stand:

\footnotetext{
'Apart from doing the job professionally, getting the right stuff on the record, giving answers that were verifiably true. I got into a relaxed habit of being able to play it with a bit... and got quite a bit of humour in it to lighten the atmosphere' [Baker, 2013-2014, Track 6].
}

Whatever the efforts of the witnesses, it was a courtroom drama with generally only a small audience. Although the CEGB laid on a shuttle bus to the inquiry venue, the proceedings were, 'watched on most days by a handful of people or fewer' [Young, 1985]. Newspapers reported on the inquiry, but it rarely made headline news. Whilst the CEGB won the inquiry, the environmentalists were unconvinced. 'We oppose all types of nuclear power,' said Friends of the Earth campaign manager Steve Billcliffe on the inquiry opening day [Chorlton, 1983]. Little had changed by the end. 'I very much doubt whether the vast tomes of Frank Layfield's written report changed the mind one way or another of any of the participants in the debate,' reflected John Baker [Baker, 2013-2014, Track 6].

Nevertheless this show trial of the nuclear programme was significant. Although its details were perhaps less important to the public at large than that a debate had happened, it had been seen to happen, and that it had been most thorough. Rüdig argues that the inquiry's very thoroughness 'prevented it becoming the subject of sustained public interest' and contained the anti-nuclear movement: The 
'exhaustive nature of the inquiry practically removed any serious potential for a major revival of opposition' [Rüdig, 1994, p. 88].

The inquiry cleared the way for the construction of Sizewell B and smoothed the path of its sister stations. The Hinkley $\mathrm{C}$ inquiry was a much faster affair, beginning in 1988 with the report issued in 1990. However, other events continued to demand particular public relations attention. The efforts of the Nuclear Industry Radioactive Waste Executive to find long-term nuclear waste depositories was a source of much controversy and bad publicity for the industry in the 1980s. While this was in itself partly an effort to meet public concern about what could be done about nuclear waste, it eventually resulted in defeat for the industry and the abandonment of its plans [Rüdig, 1994]. While the industry failed to convince the public and policy makers over nuclear waste disposal, its efforts to reassure in the aftermath of the 1986 Chernobyl disaster were perhaps more successful.

With the Sizewell decision still pending, Chernobyl was potentially very serious for CEGB plans. In line with the rest of the international nuclear industry, its response was to emphasise that the Soviet RBMK reactor was quite different to British designs, lacked key safety features, and had unique design flaws. These technical arguments would be key to the reassurance CEGB scientists, particularly its chairman, Walter Marshall, offered to the media. As Peter Vey recalled, the message was mainly that, 'whatever might have happened it was a dreadful, dreadful tragedy, but it could not happen in this country [Vey, 2016, Track 11]. As well as innumerable media appearances from its experts, the CEGB also issued a video to address safety concerns. Chernobyl: Could it Happen Here?, dissected in detail how the accident happened, the design flaws in the Soviet reactor and the mistakes of its operators, reassuring that 'categorically... an accident similar to that one could not happen in a British nuclear power station.' The video reprised the two main threads of CEGB public communications during this period. It first sought to reassure with reason and facts, stressing the different design of British reactors, their extensive safety features, close regulation and the thorough training of British reactor staff. It then appealed to personal experience through a series of interviews with CEGB reactor operators. 'I feel very safe working in the reactor,' says one operator. 'And the wife, the children, who are near, very near the reactor, feel very safe because I've put them in the picture of what's happened down here' [CEGB, 1986].

The British nuclear industry's approach to presenting nuclear power to the public operated on a number of complimentary levels. At times it could be technocratic, issuing facts and appealing to reason to correct what it saw as a deficit in the public's understanding of the issues. However, it simultaneously sought to engage, sending speakers to debate the issues, and offered personal experiences to help people form their own opinions, such as visits to nuclear power stations. As efforts to blend power stations with the natural and social environments around them show, its approach was sometimes indirect and surprisingly subtle too. The industry's efforts varied over the years, reaching a peak in the 1980s when growing anti-nuclear feeling, Chernobyl and the prospects for a new nuclear programme all coincided. What is clear from this overview of the industry's efforts is that its approach to the public was far more nuanced than many scholars have given it credit for. 
Further research is needed into the effects of all these efforts, but over the 1980s the industry was successful in laying the groundwork to ensure the public acceptability of a new generation of nuclear stations. However, as has been well documented elsewhere, reassessment of the long term nuclear decommissioning liabilities during the privatisation of the industry and the unattractiveness of nuclear power to investors saw these plans first placed on hold and then abandoned [Helm, 2003; Taylor, 2016].

In 1995 British Energy, the soon-to-be privatised operator of Britain's AGR and PWR stations, announced it would not proceed with Hinkley C. In the early $21^{\text {st }}$ century, with little prospect of new stations, British Energy in financial trouble, and in a climate of heightened security following the 9/11 terrorist attacks, the public relations effort was gradually wound down and the visitor centres closed. 'They were seen as an unnecessary cost and were closed. Seen as a retrograde step by many people, myself included,' reflects Peter Webster [Webster, 2016, Track 6]. However, this was not the end of the story. As older plants have closed, Britain faces a looming electricity capacity crisis. New nuclear power stations are back on the agenda and public attitudes toward nuclear power have again become important. In 2012 EDF Energy, present owner of the nuclear power stations, opened a new generation of visitor centres at British nuclear power stations. To judge from the generally enthusiastic reviews visitors have left on internet tourism sites, of how they were impressed by the technology, the safety and even the scenery, the experiential power of a visit to a nuclear power station is as a strong as ever: 'Until I made this visit I suppose any thoughts I had about Nuclear power stations were sllghtly [sic] against them on the grounds that they were dangerous, dirty and not 'Eco friendly'. How wrong I was!... I came away convinced that it is by far the best way we have to meet the ever increasing demand for electricity' [Jeff05, 2015].

Acknowledgments The authors would like to thank Jan Shearsmith, Archivist at the Museum of Science and Industry for his help in locating material for this project and all those who agreed to be interviewed for the Oral History of the Electricity Supply Industry in the UK. Their recollections have informed our understanding even if they have not been directly quoted here. We are grateful for the support of the project advisory committee and its funders, Hodson and Ludmilla Thornber. All interview extracts are (C) British Library and we are grateful for permission to include them here.

\section{References}

Baker, J. (1st March 1982). 'Sizewell B - Local opinion research'. Letter to CEGB board members, YA1989.338/386/1-2, Electricity Council Archives, Museum of Science and Industry, Manchester.

Baker, J. (2013-2014). John Baker interviewed by Thomas Lean. An Oral History of the Electricity Supply Industry in the UK. British Library, National Life Stories Collection, C1495/14.

URL: http: //explore.bl .uk/BLVU1 : LSCOP-ALL:BLLSA7698859.

BBC News (2008). '1956: Queen switches on nuclear power'. BBC News On This Day. URL: http://news.bbc.co.uk/onthisday/hi/dates/stories/october/17 /newsid_3147000/3147145.stm (visited on 3rd July 2017). 
Camsey, G. (2014). Granville Camsey interviewed by Thomas Lean. An Oral History of the Electricity Supply Industry in the UK. British Library, National Life Stories Collection, C1495/09.

URL: http: //explore.bl .uk/BLVU1 : LSCOP-ALL:BLLSA7617655.

CEGB (1986). CEGB UK Official Response to Chernobyl (1986).

URL: https://www . youtube. com/watch?v=TInLul3CCew (visited on

12th December 2016).

Chorlton, P. (12th January 1983). 'Board's assurance on Sizewell B reactor'. The Guardian, p. 5.

Clarke, F. J. P. (1st December 1981). 'Letter from F. J. P. Clarke to L. E. J. Roberts'. The National Archives, AB 57/236.

Collins, H. M. (1988). 'Public Experiments and Displays of Virtuosity: The Core-Set Revisited'. Social Studies of Science 18 (4), pp. 725-748.

DOI: $10.1177 / 030631288018004006$.

Davies, R. (1987). 'The Effectiveness of the Sizewell B Public Inquiry in Facilitating Communication about the Risks of Nuclear Power'. Science, Technology, $\mathcal{E}$ Human Values 12 (3/4), pp. 102-110.

URL: http://www. jstor.org/stable/689389.

Electricity Council (1979). 'The Need for Nuclear Power'. Electricity Council Archives. Museum of Science and Industry, Manchester, U.K. YA1989.338/386/1-2.

Gammon, M. (1981). CEGB experience in obtaining local acceptance of nuclear power stations. Seminar paper to the Uranium Institute.

- (2014). Michael Gammon interviewed by Thomas Lean. An Oral History of the Electricity Supply Industry in the UK. British Library, National Life Stories Collection, C1495/14.

URL: http://explore.bl.uk/BLVU1 : LSCOP-ALL:BLLSA7747723.

Hannah, L. (1982). Engineers, Managers and Politicians: The First Fifteen Years of Nationalised Electricity Supply in Britain. London, U.K.: Macmillan.

Helm, D. (2003). Energy, the State, and the Market: British Energy Policy Since 1979. Oxford, U.K.: Oxford University Press.

Hinton, C. and Holford, W. (1960). 'Power production and transmission in the countryside: preserving amenities'. Journal of the Royal Society of Arts 108 (5043), pp. 180-210. URL: http: //www . jstor .org/stable/41366630.

Hogg, J. (2016). British nuclear culture: official and unofficial narratives in the long 20th century. London, U.K.: Bloomsbury.

Jeff05 (14th May 2015). 'Changing my view on nuclear power stations'. Trip Advisor. URL: https://www . tripadvisor .co.uk/ShowUserReviews-g3318368-d214777r272000570-Dungeness_Power_Station_Visitor_Centre-Dungeness_Kent_Eng land.html (visited on 12th December 2016).

Langhamer, C. (7th December 2016). Mass observing emotion. Seminar paper, De Montfort University.

Marshall, W. (1984). Operation Smash Hit 1984 CEGB Original. URL: https : //www . youtube. com/watch?v=hTshPr2TogE (visited on 12th December 2016).

Maybury, P. A. (1982). 'Letter to A. Plumpton'. YA1989.338/386/1-2. Electricity Council Archives, Museum of Science and Industry, Manchester.

McInerney, T. (2014). Tom McInerney interviewed by Thomas Lean. British Library, National Life Stories Collection, C1495/26.

URL: http: //explore.bl .uk/BLVU1 : LSCOP-ALL:BLLSA7749397. 
Miller, M. (2004). 'Holford, William Graham, Baron Holford (1907-1975)'. In: The Oxford Dictionary of National Biography. Ed. by H. C. G. Matthew and

B. Harrison. Oxford: Oxford University Press. DOI: 10.1093/ref : odnb/31245.

(Visited on 5th December 2016).

Morris, M. (27th August 1986). 'Sellafield glows as tourist attraction'. The Guardian, p. 2.

- (6th August 1988). 'Thousands flock to the Sellafield Experience'. The Guardian, p. 4.

NPIG (19th June 1980). 'Don't join the train until you know where it's going'. Advert. New Scientist, p. 368.

Page, K. (11th February 1977). 'Monopoly on publicity pile'. The Guardian, p. 1.

Rippon, S. (1968). 'The Nuclear Landscape'. Country Life Annual, pp. 79-82.

Royal Commission on Environmental Pollution (1976). Sixth Report: Nuclear Power and the Environment. Cmnd 6618. London, U.K.: HMSO.

Rüdig, W. (1994). 'Maintaining a Low Profile: The Anti-nuclear Movement and the British State'. In: States and Anti-Nuclear Movements. Ed. by H. Flam. Edinburgh, U.K.: Edinburgh University Press, pp. 70-100.

Sheail, J. (1991). Power in trust: the environmental history of the Central Electricity Generating Board. Oxford, U.K.: Clarendon Press.

Taylor, S. (2016). The fall and rise of nuclear power in Britain. Cambridge, U.K.: UIT Cambridge.

The Guardian (13th February 1958). 'Villagers United In Support Of Power Station: "Bread before beauty" theme at inquiry'. The Manchester Guardian, p. 9.

- (16th November 1962). 'A blend of power and park: Trawsfynydd at half-way stage'. The Guardian, p. 13.

- (26th October 1967). 'Lure of nuclear power stations'. The Guardian, p. 5.

Vey, P. (2016). Peter Vey interviewed by Thomas Lean. An Oral History of the Electricity Supply Industry in the UK. British Library, National Life Stories Collection, C1495/51. URL: http://explore.bl .uk/BLVU1 : LSCOP-ALL:BLLSA7853633.

Webster, P. (2016). Peter Webster interviewed by Thomas Lean. An Oral History of the Electricity Supply Industry in the UK. British Library, National Life Stories Collection, C1495/50.

Welsh, I. (1989). 'Nuclear Nation Local Reaction'. The Journal of Regional and Local Studies 9-10, pp. 1-28.

- (1993). 'The NIMBY Syndrome: Its Significance in the History of the Nuclear Debate in Britain'. The British Journal for the History of Science 26 (1), pp. 15-32. URL: http://www . jstor.org/stable/4027338.

- (2000). Mobilising modernity: the nuclear moment. London, U.K.: Routledge.

Wynne, B. (1982). Rationality and ritual: The Windscale inquiry and nuclear decisions in Britain. Chalfont St Giles, U.K.: British Society for the History of Science Monographs.

Young, D. (8th March 1985). 'Letter from Sizewell. Longest inquiry ends as it began'. The Times, p. 30. 
Thomas Lean is a project interviewer for two National Life Stories projects; An Oral History of British Science and An Oral History of the Electricity Supply Industry in the UK. He completed his PhD on home computing in the 1980s at the Centre for the History of Science, Technology and Medicine, University of Manchester. His book, Electronic Dreams, was published by Bloomsbury in 2016.

E-mail: thomas.lean@bl.uk.

Sally Horrocks is based in the School of History, Politics and International Relations at the University of Leicester and is academic advisor to An Oral History of British Science and An Oral History of the Electricity Supply Industry in the UK. She has published primarily on industrial research, women chemists and food science and was President of the British Society for the History of Science from 2010 to 2012. E-mail: smh4@le.ac.uk.

\section{How to cite}

Lean, T. and Horrocks, S. (2017). 'Good Nuclear Neighbours: the British electricity industry and the communication of nuclear power to the public, 1950s-1980s'. JCOM 16 (03), A09. 